\title{
フッ素系ジェミニ型界面活性剂
}

\section{Fluorinated Gemini Surfactants}

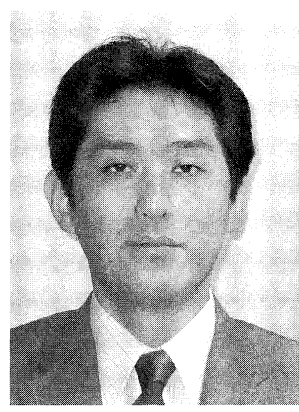

吉村 倫一

奈良女子大学 大学院 人間文化研究科.

理学部化学科

干 630-8506

奈良市北魚屋西町

Tomokazu YOSHIMURA

Graduate School of Humanities and Sciences,

Department of Chemistry, Faculty of Science,

Nara Women's University

Kitauoyanishi-machi, Nara 630-8506, JAPAN

論文要旨：ジェミニ型界面活性剂は従来の界面活性剂と比べて低い臨界ミセル濃度（cmc）や高い表面張 力低下能など優れた界面活性を有し，水溶液中での低濃度においてプレミセル形成や自発的ベシクル形成な どユニークな会合挙動を示すことが知られている。これまでに報告されているジェミニ型界面活性剤のほと んどは，疎水基に炭化水素鎖を含むものであるが，筆者らは，研究例の少ないフッ化炭素鎖を有するフッ素 系ジェミニ型界面活性剤に着目して研究を行ってきた。本稿では，（1）カルボン酸塩を有するフッ素系ジェ ミニ型アニオン界面活性剤，（2）四級アンモニウム塩を有するフッ素系ジェミニ型カチオン界面活性剤，(3) フッ化炭素と炭化水素の異種の疎水鎖を有するハイブリッドジェミニ型カチオン界面活性剂の分子設計・合 成， $\mathrm{cmc}$ や表面張力などの界面化学的性質ならびに水溶液中で形成する会合体の特性について紹介する。

Abstract: Gemini surfactants are known to have high surface activities such as lower critical micelle concentration ( $\mathrm{cmc}$ ) and higher efficiency in lowering the surface tension than conventional surfactants, and show unique aggregation behavior such as premicellar aggregate formation and spontaneous vesicle formation at low concentration in solution. Although most gemini surfactants that have been reported so far, contain hydrocarbon chains as hydrophobic group, the authors pay attention to fluorinated gemini surfactants with one or two fluorocarbon chains in a molecule, and have been researching. Only a few reports are available with regard to research on fluorinated gemini surfactants. Design and synthesis, surface-active properties such as cmc and ability in reducing the surface tension, and aggregation properties in aqueous solution for (1) fluorinated anionic gemini surfactants with carboxylate salts, (2) fluorinated cationic gemini surfactants with quaternary ammonium salts, (3) hybridgemini surfactants with different chains of fluorocarbon and hydrocarbon are reviewed in the present study.

Key words: gemini surfactant, fluorinated surfactant, hybridgemini surfactant, surface-active property, aggregation property

\section{1 はじめに}

ジェミ二型界面活性剤は界面活性剂同士が適当な連結 基により繋がれた構造で，分子内に 2 本の疎水鎖と $2 つ$ の親水基をもつ。ジェミ二型界面活性剤の多くは，一般 の 1 疎水鎖 1 親水基型の界面活性剂と比較して, 1 3 桁低い臨界ミセル濃度 (cmc) や低い表面張力などの優 れた界面活性を有し，水溶液中において $\mathrm{cmc}$ 付近の低

連絡者：吉村 倫一

E-mail : yoshimura@cc.nara-wu.ac.jp
濃度でのプレミセル形成や自発的なベシクル形成など特

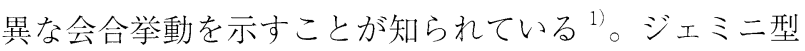
界面活性剂の研究は, 1990 年頃から Okahara ${ }^{2}$, Menger $^{3)}$, Zana ${ }^{4)}$, Rosen ${ }^{5)}$ らの研究グループを中心に 精力的に行われ，新しい構造の分子設計・合成から物理 化学的性質の研究まで幅広く行われてきた。疎水基, 親 水基㧍よび連結基を変えることで多種多様な構造のジエ ミ二型界面活性剤の分子設計が可能であり，20 年経過 した現在でも研究者の興味は尽きることなく研究は進展 し続けている。近年では, ジェミ二型界面活性剤は次世 
代型界面活性剂として注目されており, 実用化も行われ るようになった。しかし, これらのジェミニ型界面活性 剤は踈水基として炭化水素鎖を有するものがほとんどで あり，炭化水素鎖中の水素原子の一部またはすべてを フッ素原子で置き換えたフッ化炭素鎖を有するフッ素系 ジェミニ型界面活性剤の研究は比較的少ない ${ }^{6-22)}$ 。これ はフッ素原子の電気㓌性度が大きく電子を強く引きつけ て他原子との反応性が低いために，合成が困難であるこ とが大きな理由と考えられる。また, 連結基にフッ化炭 素を有するジェミ二型界面活性剤の研究も行われてい る ${ }^{23,24)}$ 。フッ素原子は原子半径および分極率が小さく, 電気㓌性度はあらゆる元素の中で最も高く, また, 炭素 ーフッ素結合の結合エネルギーが大きいといった性質を 有することから, フッ素系界面活性剤は, 炭化水素系界 面活性剤と比較して低い $\mathrm{cmc}$ や高い表面張力低下能な どの高い界面活性を示し, 耐熱性および耐薬品性に優れ ていることが知られている ${ }^{25)}$ 。

本稿では, Fig. 1 に示すようなカルボン酸塩のアニオ ンおよび四級アンモニウム塩のカチオンの 2 種類のフッ 素系ジェミ二型界面活性剤の合成, 界面化学的性質, 水 溶液中での会合体特性について, 筆者らの研究を中心に 紹介する。また, 分子内にフッ化炭素と炭化水素の異種 の疎水鎖を有する四級アンモニウム塩のハイブリッド ジェミニ型カチオン界面活性剂についても解説する。

\section{2 フッ素系ジェミニ型アニオン界面活性剤}

フッ素系ジェミニ型界面活性剂の研究は, 四級アンモ ニウム塩のカチオン型が最も多く, アニオン型のものは 少ない。ここでは, 親水基にカルボン酸塩を有するフッ 素系ジェミニ型アニオン界面活性剤の合成, 界面化学的 性質 ${ }^{20)}$ および水溶液中での会合体特性 ${ }^{18)}$ について紹介 する。

カルボン酸基を有するフッ素系ジェミニ型界面活性剤 $\left(2 \mathrm{C}_{n}^{\mathrm{F}} \mathrm{edda}, n\right.$ はフッ化炭素鎖長で $\left.4,6,8\right)$ は, エチ レンジアミンー $N, N^{\prime}$ - 二酢酸と 3 -ペルフルオロアル キルー 1,2-エポキシプロパンをメタノール溶媒中, 水 酸化ナトリウム添加によるアルカリ条件下で約 50 時間 反応させることにより得られる。

電位差 $\mathrm{pH}$ 滴定より $2 \mathrm{C}_{n}{ }^{\mathrm{F}} \mathrm{edda}$ の酸解離定数 $(\mathrm{p} K)$ は, $2 \mathrm{C}_{4}^{\mathrm{F}}$ edda が $\mathrm{p} K_{1}=8.3, \quad \mathrm{p} K_{2}=5.1,2 \mathrm{C}_{6}{ }^{\mathrm{F}}$ edda $\mathrm{p} K_{2}=4.6,2 \mathrm{C}_{8}^{\mathrm{F}}$ edda が $\mathrm{p} K_{1}=8.1, \mathrm{p} K_{2}=4.1$ であること から, 水溶液中での測定で用いる $\mathrm{pH} 12 \sim 13(0.1$

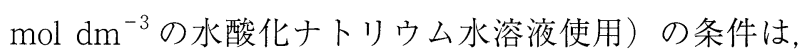
親水基が完全にカルボキシルイオンになっている。一般 に, フッ素系界面活性剤は水への溶解性が低いが, $2 \mathrm{C}_{n}{ }^{\mathrm{F}} \mathrm{edda}$ は 2 本のフッ化炭素鎖を有するにもかかわら ず 2 つカルボキシルイオンを含有しているために, $\mathrm{pH}$ 12〜13 のアルカリ水溶液に対して良好な水溶性を示 す。 $25^{\circ} \mathrm{C}$ での表面張力曲線より得られる $2 \mathrm{C}_{n}{ }^{\mathrm{F}}$ eddaの $\mathrm{cmc}, \mathrm{cmc}$ における表面張力 $\left(\gamma_{\mathrm{cmc}}\right)$, 分子占有面積 $(A)$, 吸着の標準自由エネルギー $\left(\Delta G^{\circ}{ }_{\text {ads }}\right)$ の值を Table 1 に 示す。フッ化炭素鎖長が 6 のときに最も低い $\mathrm{cmc}$ と小 さな $\gamma_{\mathrm{cmc}}$ 值を示し, 気/液界面に効率よく吸着・配向し ていることがわかる。鎖長が 6 から 8 に長くなると $\mathrm{cmc}$ が増加する異常な現象は, 炭化水素系の長い鎖をもつ ジェミニ型界面活性剂でしばしば認められ，これは $\mathrm{cmc}$ 以下の低濃度で 2,3 量体のプレミセル形成に基づくとの 報告 ${ }^{26-28)}$ もあるが，詳細はわかっていない。 $2 \mathrm{C}_{n}{ }^{\mathrm{F}}$ edda の $\mathrm{cmc}$ は, 一般のフッ素系アニオン界面活性剂 $\mathrm{C}_{7} \mathrm{~F}_{15-}$ $\mathrm{COONa}$ の $\mathrm{cmc}\left(30 \mathrm{mmol} \mathrm{dm}{ }^{-3}\right)^{29)}$ と比べてもはるかに 小さく, ジェミニ型界面活性剤の特徴が現れている。ま た, $2 \mathrm{C}_{n}^{\mathrm{F}}$ eddaは, $\mathrm{C}_{7} \mathrm{~F}_{15} \mathrm{COONa} の \gamma_{\mathrm{cmc}}\left(47.4 \mathrm{mN} \mathrm{m}^{-1}\right)^{30)}$ と比べてもかなり大きな表面張力の低下を示す。鎖長が 6 から 8 に長くなると $\gamma_{\mathrm{cmc}}$ は $10 \mathrm{mN} \mathrm{m}^{-1}$ 程度高くなり, 界面での配向性は低下する。一方, $2 \mathrm{C}_{n}^{\mathrm{F}} \mathrm{edda}$ の分子占 有面積 $A$ は, 鎖長の増加に伴い小さくなり,これはフッ

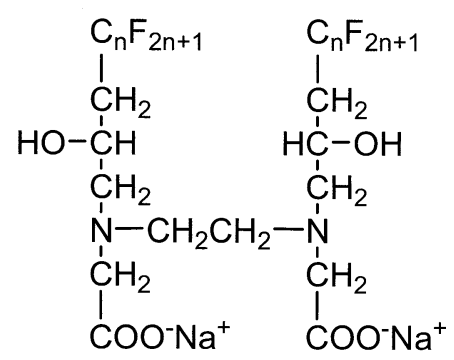

$2 \mathrm{C}_{n}{ }^{\mathrm{F}}$ edda $(n=4,6,8)$<smiles>C[N+](C)(Br)CC[N+](C)(C)CCC(O)CC(O)CF</smiles>

$\mathrm{C}_{n}{ }^{\mathrm{F}} \mathrm{C}_{3}-2-\mathrm{C}_{3} \mathrm{C}_{n}{ }^{\mathrm{F}}(n=4,6,8)$

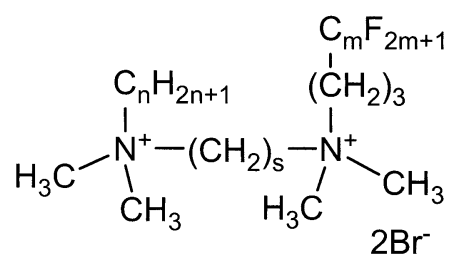

$$
\begin{aligned}
& \mathrm{C}_{n}-s-\mathrm{C}_{3} \mathrm{C}_{m}{ }^{\mathrm{F}} \quad(n=8,10,12, \\
& m=6,8, s=2,3,6,8,10,12)
\end{aligned}
$$

Fig. 1 Chemical structures of fluorinated anionic gemini surfactant $\left(2 \mathrm{C}_{n}^{\mathrm{F}}\right.$ edda), fluorinated cationic gemini surfactant $\left(\mathrm{C}_{n}{ }^{\mathrm{F}} \mathrm{C}_{3}-2-\mathrm{C}_{3} \mathrm{C}_{n}^{\mathrm{F}}\right)$, and fluorocarbon/hydrocarbon cationic hybridgemini surfactant $\left(\mathrm{C}_{n}-\mathrm{s}-\mathrm{C}_{3} \mathrm{C}_{m}{ }^{\mathrm{F}}\right)$. 
Table 1 Surface-active properties obtained by surface tension plots of $2 \mathrm{C}_{n}^{\mathrm{F}}$ edda.

\begin{tabular}{ccccc}
\hline Surfactant & $\begin{array}{c}\mathrm{cmc} \\
\left(\mathrm{mmol} \mathrm{dm}^{-3}\right)\end{array}$ & $\begin{array}{c}\gamma_{\mathrm{cmc}} \\
\left(\mathrm{mN} \mathrm{m}^{-1}\right)\end{array}$ & $\begin{array}{c}A \\
\left(\mathrm{~nm}^{2} / \mathrm{molecule}\right)\end{array}$ & $\begin{array}{c}\Delta G^{\circ} \text { ads } \\
\left(\mathrm{kJ} \mathrm{mol}^{-1}\right)\end{array}$ \\
\hline $2 \mathrm{C}_{4}{ }^{\mathrm{F}}$ edda & 0.484 & 18.4 & 0.944 & -45.4 \\
$2 \mathrm{C}_{6}{ }^{\mathrm{F}}$ edda & 0.00516 & 16.4 & 0.610 & -41.4 \\
$2 \mathrm{C}_{8}{ }^{\mathrm{F}}$ edda & 0.0324 & 26.9 & 0.538 & -33.3 \\
\hline
\end{tabular}

化炭素鎖が長くなると鎖間の相互作用が強まり，気／液 界面に密に吸着していることを示す。しかし，鎖が長く なり過ぎると界面が高密度となり (小さな $A$ 值), 配向 が低下する (大きな $\gamma_{\mathrm{cmc}}$ 值) ものと考えられる。吸着の 標準自由エネルギー $\Delta G^{\circ}{ }_{\text {ads }}$ の絶対值は, フッ化炭素鎖 長の増加とともに小さくなり，界面吸着よりも水溶液中 でのミセル形成が起こりやすいことが示唆される。

$\mathrm{pH}$ 12 13 の水溶液で $2 \mathrm{C}_{n}^{\mathrm{F}} \mathrm{edda}$ が形成する会合体に ついて, 動的光散乱 (DLS) より得られた $2 \mathrm{C}_{n}{ }^{\mathrm{F}} \mathrm{edda} の$ 会合体の見かけの流体力学的半径と濃度の関係を Fig. 2 に示す。 $2 \mathrm{C}_{n}^{\mathrm{F}} \mathrm{e}$ edda の会合体のサイズは, 炭化水素系ジェ ミ二型界面活性剤の会合体と比べてかなり大きい。 $2 \mathrm{C}_{4}{ }^{\mathrm{F}}$ edda およひび $2 \mathrm{C}_{8}{ }^{\mathrm{F}}$ edda の会合体のサイズは濃度の増 加とともに大きくなるのに対し， $2 \mathrm{C}_{6}{ }^{\mathrm{F}} \mathrm{edda}$ は濃度増加 に伴い, 半径約 $270 \mathrm{~nm}$ の会合体が極大となって検出さ れ，さらに濃度が増加するとそのサイズは約 $80 \mathrm{~nm}$ ま で小さくなる。この特異な会合挙動は, $2 \mathrm{C}_{6}{ }^{\mathrm{F}}$ edda の疎 水鎖が rigid なフッ化炭素と flexible な炭化水素から成 ることが理由の一つとして考えられる。炭化水素系ジエ ミ二型界面活性剤やフッ素系 1 鎖型界面活性剤ではこの

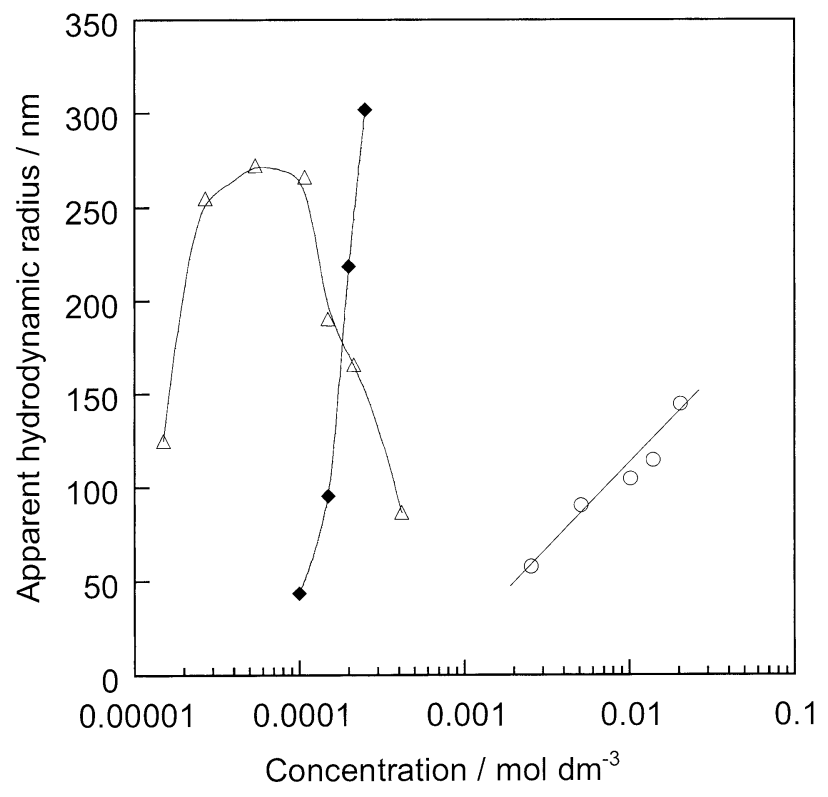

Fig. 2 Change in apparent hydrodynamic radius with the concentration of $2 \mathrm{C}_{n}^{\mathrm{F}}$ edda $(n=4,6,8) . \bigcirc, n=4 ; \triangle$, $n=6 ;, n=8$.
ような挙動は認められず，大変興味深い結果であると言 える。 $2 \mathrm{C}_{6}^{\mathrm{F}}$ eddaの $0.21 \mathrm{mmol} \mathrm{dm}{ }^{-3}$ における会合体のフ リーズフラクチャー法による透過型電子顕微鏡 (FFTEM）写真をFig. 3 に示す。確認された構造はべシク ルのような大きな会合体であり，そのサイズはDLSよ り得られた粒径とほぼ一致する。2 $\mathrm{C}_{4}^{\mathrm{F}}$ eddaおよび $2 \mathrm{C}_{8}{ }^{\mathrm{F}}$ eddaについてはTEM 観察より，それぞれ紐状 (string-like）の会合体, ベシクルを形成していることが

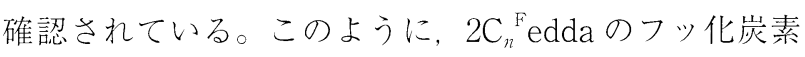
鎖長および濃度を変えることにより，形成する会合体の 構造やサイズが劇的に変化することは大変興味深い。

\section{3 フッ素系ジェミニ型カチオン界面活性剤}

Oda らは, 親水基に四級アンモニウム塩, 疎水基に ペルフルオロオクチルブチル鎖を有するフッ素系ジェミ 二型カチオン界面活性剂を分子設計 ·合成し, 水溶液中 で 15〜200 nm の大きさのユニラメラベシクルを形成す ることを報告した ${ }^{8)}$ 。この研究がフッ素系ジェミ二型界 面活性剂の始まりといってもよい。しかし，この合成方
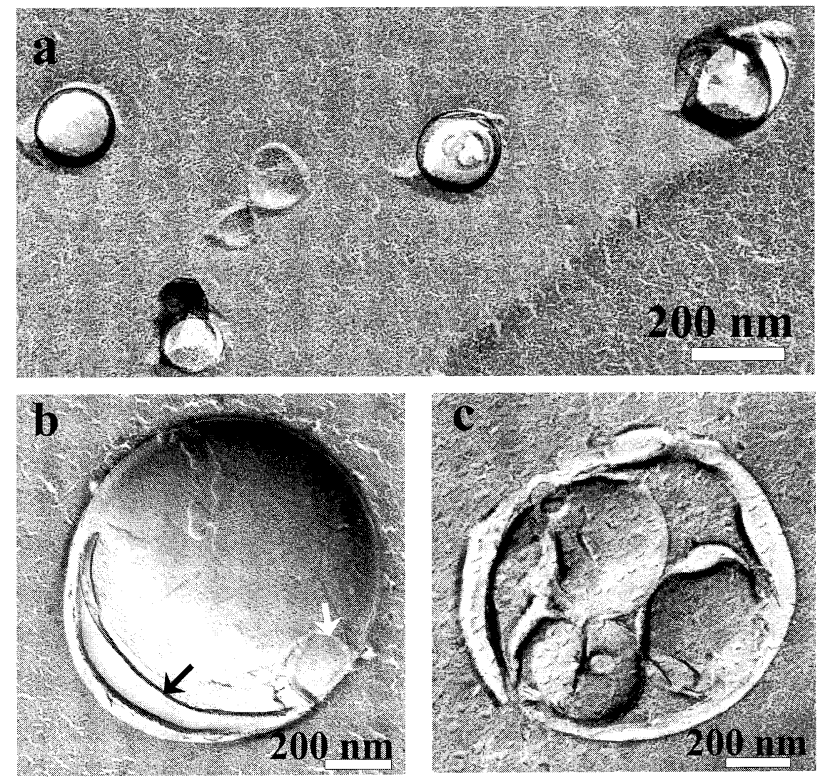

Fig. 3 Freeze-Fracture TEM micrographs of $2 \mathrm{C}_{6}{ }^{\mathrm{F}}$ edda solution at $0.21 \mathrm{mmol} \mathrm{dm} \mathrm{m}^{-3}$ (a). The leaflike bilayer sheet (black arrow) and the source (white arrow) can be distinctly seen in $b$. The complicated nanocage aggregate is also seen in c. 
法は多数のステップから成るため, 収率よくかつ純度よ く目的物を得るのはかなり難しい。そこで著者らは, そ のような問題を解決すべく, フッ化炭素鎖の原料に $3-$ ペルフルオロアルキルー1,2-エポキシプロパンを用い てアプローチを行った。ここでは, 筆者らが手がけた疎 水基にペルフルオロアルキルー 2 -ヒドロキシプロピル 鎖を有する四級アンモニウム塩のフッ素系ジェミニ型力 チオン界面活性剂の合成, 界面化学的性質 ${ }^{14)}$ および水 溶液中での会合体特性 ${ }^{17)}$ について紹介する。

四級アンモニウム塩を有するフッ素系ジェミニ型界面 活性剂 $\left(\mathrm{C}_{n}{ }^{\mathrm{F}} \mathrm{C}_{3}-2-\mathrm{C}_{3} \mathrm{C}_{n}{ }^{\mathrm{F}}, n\right.$ はフッ化炭素鎖長で 4, 6, 8)

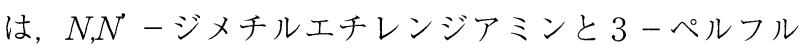
オロアルキルー 1,2 -エポキシプロパンの反応により得

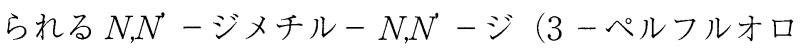
アルキルー 2 -ヒドロキシプロピル）エチレンジアミン と過剩量のヨウ化メチルの四級化反応を行い, 対イオン を臭素イオンに交換することにより得られる。

$\mathrm{C}_{n}{ }^{\mathrm{F}} \mathrm{C}_{3}-2-\mathrm{C}_{3} \mathrm{C}_{n}{ }^{\mathrm{F}}$ は $25^{\circ} \mathrm{C}$ で高い水溶性を示す。表面張力 曲線より得られる $\mathrm{C}_{n}{ }^{\mathrm{F}} \mathrm{C}_{3}-2-\mathrm{C}_{3} \mathrm{C}_{n}{ }^{\mathrm{F}}$ の $\mathrm{cmc}, \mathrm{cmc}$ における 表面張力 $\left(\gamma_{\mathrm{cmc}}\right)$, 分子占有面積 $(A)$, 吸着の標準自由 エネルギー $\left(\Delta G^{\circ}{ }_{\text {ads }}\right)$ の值を Table 2 に示す。 $\mathrm{C}_{n}{ }^{\mathrm{F}} \mathrm{C}_{3}{ }^{-}$ $2-\mathrm{C}_{3} \mathrm{C}_{n}^{\mathrm{F}}$ の $\gamma_{\mathrm{cmc}}$ は, 対応する四級アンモニウム塩の炭化 水素系ジェミ二型界面活性剂 $\left(\mathrm{C}_{m}-2-\mathrm{C}_{m}, m\right.$ は炭化水素 鎖長で $m=10$ のとき $\gamma_{\mathrm{cmc}}=32 \mathrm{mN} \mathrm{m}^{-1}, m=12$ のとき $\left.\gamma_{\mathrm{cmc}}=40 \mathrm{mN} \mathrm{m}^{-1}\right)^{31)}$ と比べてかなり低い值であり,また, 一般のフッ素系 1 鎖型界面活性剤 $\left(\gamma_{\mathrm{cmc}}=15 \sim 20\right.$ $\left.\mathrm{mNm}^{-1}\right)^{30,32,33)}$ と比べて同等あるいは低い值であり, ジェ ミ二型界面活性剤とフッ素系界面活性剤の両方の特性が 十分に発揮されていることがわかる。一般に, フッ素系 界面活性剂の $\mathrm{cmc}$ はそのフッ化炭素鎖長の 1.5 倍の炭素 鎖を有する炭化水素系界面活性剤の $\mathrm{cmc}$ にほぼ等しい ことが知られている ${ }^{34)}$ 。 $\mathrm{C}_{n}{ }^{\mathrm{F}} \mathrm{C}_{3}-2-\mathrm{C}_{3} \mathrm{C}_{n}{ }^{\mathrm{F}}$ の疎水鎖のヒド ロキシル基を無視すると, フッ化炭素鎖長 6 の $\mathrm{C}_{6}{ }^{\mathrm{F}} \mathrm{C}_{3}-2$ $\mathrm{C}_{3} \mathrm{C}_{6}{ }^{\mathrm{F}}$ の $\mathrm{cmc}$ は, 炭化水素鎖長 12 の $\mathrm{C}_{12}-2-\mathrm{C}_{12}$ の $\mathrm{cmc}$ と ほぼ等しいと予想されるが, 実際は前者が後者よりも 6.4 分の 1 ほど小さい。これより, 凝集エネルギーの小さい 2 本のフッ化炭素鎖を束ねたジェミ二型構造にすること で, $\mathrm{cmc}$ を小さくできることがわかる。また, $\mathrm{C}_{n}{ }^{\mathrm{F}} \mathrm{C}_{3^{-}}$ $2-\mathrm{C}_{3} \mathrm{C}_{n}{ }^{\mathrm{F}}$ の $\mathrm{cmc}$ の対数は, フッ化炭素鎖長の増加ととも
に直線的に減少する。一般の炭化水素系直鎖状界面活性 剂において, $\mathrm{cmc}$ と炭化水素鎖の炭素原子数 $(N)$ の間 には, $\log \mathrm{cmc}=A-B N$ ( $A, B$ は定数 $)$ の関係が成立し, $25^{\circ} \mathrm{C}$ でアニオンおよびカチオン界面活性剤の場合, $B$ 值 は約 0.3 , 両性および非イオン性界面活性剤の場合, $B$ 值は約 0.5 であることが経験的に知られている ${ }^{35)}$ 。そこ で，フッ化炭素鎖の 1.5 倍の鎖長に 2 -ヒドロキシプロ ピル鎖の炭素鎖長の 3 を加えた長さを $N$ としてこの式 を適用すると， $B$ 值は 0.55 と見積もられる。この值は 一般のカチオン界面活性剂や四級アンモニウム塩のジェ ミ二型界面活性剂 $(B=0.41)^{36)}$ と比べて大きく，これ は鎖長増加に伴う $\mathrm{cmc}$ の変化が, フッ素系ジェミ二型 界面活性剤に対して顕著であることを示している。 $\mathrm{C}_{n}{ }^{\mathrm{F}} \mathrm{C}_{3}-2-\mathrm{C}_{3} \mathrm{C}_{n}{ }^{\mathrm{F}}$ の $\mathrm{cmc}$ は, フッ化炭素鎖よりも $1.7 \sim 1.8$ 倍長い炭化水素鎖をもつ炭化水素系ジェミ二型界面活性 剤にほぼ等しく, この 1.7〜 1.8 倍は, 報告されているフッ 素系 1 鎖型界面活性㓮の 1.5 1.7 倍 ${ }^{31,37,38)}$ よりも大きい。 なお，カチオンの $\mathrm{C}_{n}{ }^{\mathrm{F}} \mathrm{C}_{3}-2-\mathrm{C}_{3} \mathrm{C}_{n}{ }^{\mathrm{F}}$ では，前述したアニオ ンの $2 \mathrm{C}_{n}^{\mathrm{F}}$ edda で見られたプレミセル現象は認められな い。一方, $\mathrm{C}_{n}{ }^{\mathrm{F}} \mathrm{C}_{3}-2-\mathrm{C}_{3} \mathrm{C}_{n}{ }^{\mathrm{F}}$ の $A$ および $\Delta G^{\circ}{ }_{\text {ads }}$ の絶対值は, $2 \mathrm{C}_{n}^{\mathrm{F}} \mathrm{edda}$ とは異なり，鎖長の増加に伴い大きくなる傾 向が見られる。

水溶液中で $\mathrm{C}_{n}{ }^{\mathrm{F}} \mathrm{C}_{3}-2-\mathrm{C}_{3} \mathrm{C}_{n}{ }^{\mathrm{F}}$ が形成する会合体は, フッ 化炭素鎖長および濃度を変えることによって構造が劇的 に変化し，大変興味深い。 $\mathrm{C}_{n}{ }^{\mathrm{F}} \mathrm{C}_{3}-2-\mathrm{C}_{3} \mathrm{C}_{n}{ }^{\mathrm{F}}$ の会合体の染 色法による TEM 写真を Fig. 4 に示す。 $\mathrm{C}_{4}{ }^{\mathrm{F}} \mathrm{C}_{3}-2-\mathrm{C}_{3} \mathrm{C}_{4}{ }^{\mathrm{F}}$ で は，低濃度 $(\mathrm{cmc} \times 3)$ でベシクルのような大きな会合 体（a）を形成し，濃度をわずかに増加させると DLSよ り得られた見かけの流体力学的半径は 20〜 30 nm とな り, 歪んだ構造の会合体 (b) へと変化する。 $\mathrm{C}_{6}{ }^{\mathrm{F}} \mathrm{C}_{3}-2$ $\mathrm{C}_{3} \mathrm{C}_{6}{ }^{\mathrm{F}}$ では，低濃度 $(\mathrm{cmc} \times 5)$ で紐状（string-like）の ミセル（c）を形成し, 濃度増加でベシクルが出現して, 紐状（string-like）のミセルとベシクルの異種の会合体 が共存する $(\mathrm{d}) 。 \mathrm{C}_{8}{ }^{\mathrm{F}} \mathrm{C}_{3}-2-\mathrm{C}_{3} \mathrm{C}_{8}{ }^{\mathrm{F}}$ では, $\mathrm{cmc} \times 15 \sim 40$ の 濃度でベシクルを形成するが, 比較的高濃度では多分散 となり，小さなサイズのベシクルと大きなサイズのベシ クルが存在する（e, f, g)。

Table 2 Surface-active properties obtained by surface tension plots of $\mathrm{C}_{n}{ }^{\mathrm{F}} \mathrm{C}_{3}-2-\mathrm{C}_{3} \mathrm{C}_{n}{ }^{\mathrm{F}}$

\begin{tabular}{ccccc}
\hline Surfactant & $\begin{array}{c}\mathrm{cmc} \\
\left(\mathrm{mmol} \mathrm{dm}^{-3}\right)\end{array}$ & $\begin{array}{c}\gamma_{\mathrm{cmc}} \\
\left(\mathrm{mN} \mathrm{m}^{-1}\right)\end{array}$ & $\begin{array}{c}A \\
\left(\mathrm{~nm}^{2} / \mathrm{molecule}\right)\end{array}$ & $\begin{array}{c}\Delta G^{\circ} \text { ads } \\
\left(\mathrm{kJ} \mathrm{mol}^{-1}\right)\end{array}$ \\
\hline $\mathrm{C}_{4}{ }^{\mathrm{F}} \mathrm{C}_{3}-2-\mathrm{C}_{3} \mathrm{C}_{4}{ }^{\mathrm{F}}$ & 11.3 & 20.3 & 1.11 & -42.2 \\
$\mathrm{C}_{6}{ }^{\mathrm{F}} \mathrm{C}_{3}-2-\mathrm{C}_{3} \mathrm{C}_{6}{ }^{\mathrm{F}}$ & 0.172 & 19.8 & 1.31 & -54.6 \\
$\mathrm{C}_{8}{ }^{\mathrm{F}} \mathrm{C}_{3}-2-\mathrm{C}_{3} \mathrm{C}_{8}{ }^{\mathrm{F}}$ & 0.00593 & 13.7 & 1.37 & -69.3 \\
\hline
\end{tabular}



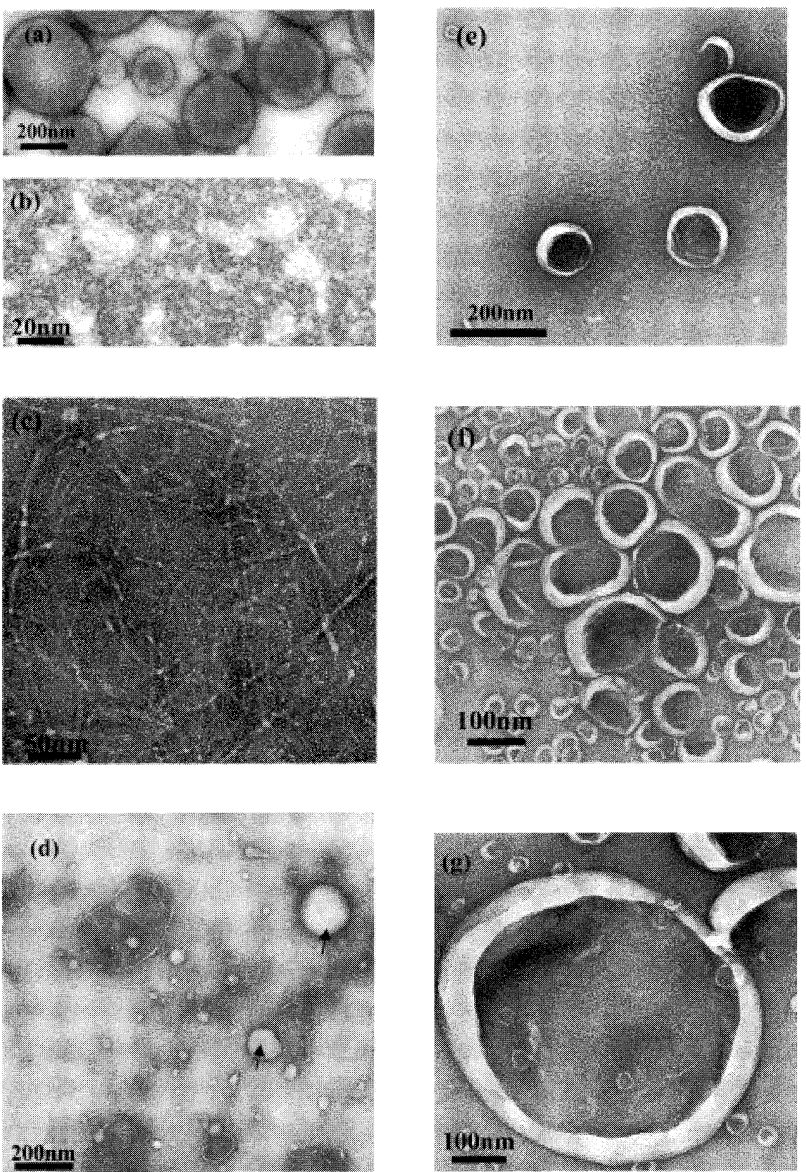

Fig. 4 TEM images of $\mathrm{C}_{n}{ }^{\mathrm{F}} \mathrm{C}_{3}-2-\mathrm{C}_{3} \mathrm{C}_{n}{ }^{\mathrm{F}}(n=4,6,8)$ aggregates. $\mathrm{C}_{4}{ }_{4} \mathrm{C}_{3}-2-\mathrm{C}_{3} \mathrm{C}_{4}{ }^{\mathrm{F}}$ at (a) $33.9 \mathrm{mmol} \mathrm{dm}{ }^{-3}$ ( $\mathrm{cmc}$ $\times 3)$ and (b) $56.5 \mathrm{mmol} \mathrm{dm}{ }^{-3}(\mathrm{cmc} \times 5), \mathrm{C}_{6}{ }^{\mathrm{F}} \mathrm{C}_{3}-2$ $\mathrm{C}_{3} \mathrm{C}_{6}{ }^{\mathrm{F}}$ at $(\mathrm{c}) 0.86 \mathrm{mmol} \mathrm{dm}^{-3}(\mathrm{cmc} \times 5)$ and (d) $2.6 \mathrm{mmol}$ $\mathrm{dm}^{-3}(\mathrm{cmc} \times 15), \mathrm{C}_{8}{ }^{\mathrm{F}} \mathrm{C}_{3}-2-\mathrm{C}_{3} \mathrm{C}_{8}{ }^{\mathrm{F}}$ at (e) $0.09 \mathrm{mmol}$ $\mathrm{dm}^{-3}(\mathrm{cmc} \times 15)$ and $(\mathrm{f}, \mathrm{g}) \quad 0.24 \mathrm{mmol} \mathrm{dm} \mathrm{dm}^{-3}(\mathrm{cmc}$ $\times 40)$. The arrows in micrograph (d) indicate the large aggregate.

\section{4 フッ化炭素/炭化水素ハイブリッドジェミニ型カチ オン界面活性剤}

分子内にフッ化炭素と炭化水素の異種の疎水鎖を有す る 2 本鎖型はハイブリッド界面活性剂として知られ, Guo や Yoshino, Kondo らによって精力的に研究が行わ

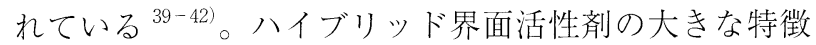
は炭化水素系抢よびフッ化炭素系界面活性剤の両方の優 れた性質を併せもつ点であり，熱応答性粘弾性挙動など, それぞれ単独系および混合系では認められないユニーク な特性を示す。しかし， 2 本鎖 1 親水基型構造のハイブ リッド界面活性剂は，鎖が長くなるとクラフト温度が高 くなって水溶性が低下するために，室温付近での実用的 な使用が困難である。そこで筆者らは, 水溶性ならびに 界面活性の向上を目指して, 分子内にフッ化炭素と炭化 水素の異種の踈水鎖を有し，2 個の親水基（四級アンモ
ニウム塩）を導入した構造のハイブリッドジェミニ型界 面活性剤の開発 ${ }^{43)}$ を行った。ここでは，その合成，界 面化学的性質ならびに水溶液中での会合体特性について 紹介する。ハイブリッドジェミニ型界面活性剂の主な研

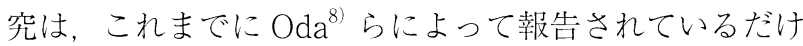
であり，今後の展開が期待される。

分子内にフッ化炭素と炭化水素の異種の蹯水鎖と四級 アンモニウム塩を有するハイブリッドジェミニ型界面活 性剂 $\left(\mathrm{C}_{n}-s-\mathrm{C}_{3} \mathrm{C}_{m}{ }^{\mathrm{F}}, n\right.$ は炭化水素鎖長で $8,10,12, m$ はフッ化炭素鎖長で $6 ， 8 ， s$ は連結鎖長で $2 ， 3 ， 6 ， 8$, 10，12）は， $N, N, N^{\prime}, N^{\prime}$ - テトラメチルジアミノアル カンと臭化アルキルの四級化反応により1本の炭化水素 鎖を導入し，次いで 3 - (ペルフルオロアルキル) プロ ピルブロミドの四級化反応により得られる。

$\mathrm{C}_{n}-\mathrm{s}-\mathrm{C}_{3} \mathrm{C}_{m}{ }^{\mathrm{F}}$ の $0.2 \mathrm{wt} \%$ 水溶液に抄けるクラフト温度は いずれも $5{ }^{\circ} \mathrm{C}$ 以下であり，対応する同種の疎水鎖を有す る炭化水素系ジェミ二型界面活性剤 $\left(\mathrm{C}_{n}-\mathrm{s}-\mathrm{C}_{n}\right)$ おおよびフッ 化炭素系ジェミ二型界面活性剂 $\left(\mathrm{C}_{m}{ }^{\mathrm{F}} \mathrm{C}_{3}-\mathrm{s}-\mathrm{C}_{3} \mathrm{C}_{m}{ }^{\mathrm{F}}\right)$ と比 ベてかなり低く，異種の疎水鎖を含む八イブリッド構造 にすることで高い水溶性が認められる。電気伝導度から 得られた $\mathrm{C}_{n}-\mathrm{s}-\mathrm{C}_{3} \mathrm{C}_{m}{ }^{\mathrm{F}}$ の $\mathrm{cmc}$ の対数と炭化水素鎖長の関 係をFig. 5 に示す。一般の界面活性郕と同様に, cmc の対数は炭化水素鎖長の増加とともに直線的に低下し, 傾き（B）は0.16〜0.19 である。フッ化炭素鎖長が 6 か ら8に長くなると $\mathrm{cmc}$ は 4 5 分の 1 低下し, 鎖長増加 に伴う $\mathrm{cmc}$ の低下はフッ化炭素鎖の方が炭化水素鎖よ りも大きい。また， $\mathrm{cmc}$ は $s=2 \sim 6$ の連結鎖長に依存せ

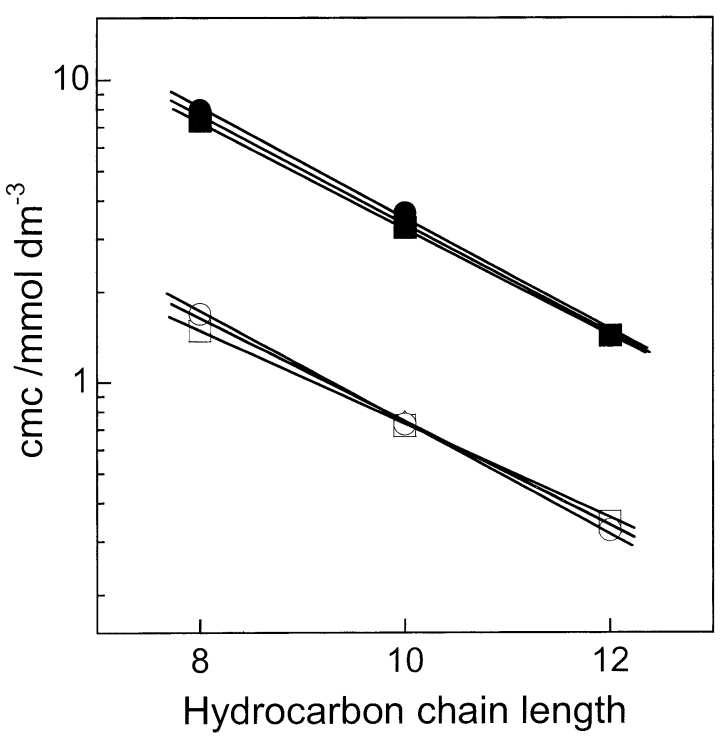

Fig. 5 Relationship between the logarithm of $\mathrm{cmc}$ and hydrocarbon chain length of $\mathrm{C}_{n}-s-\mathrm{C}_{3} \mathrm{C}_{m}{ }^{\mathrm{F}} \cdot \mathrm{C}_{n}-\mathrm{s}-\mathrm{C}_{3} \mathrm{C}_{6}{ }_{6}^{\mathrm{F}}$ : , $s=2 ; \boldsymbol{\Delta}, s=3 ; \mathbf{\square}, s=6, \mathrm{C}_{n}-s^{-} \mathrm{C}_{3} \mathrm{C}_{8}{ }^{\mathrm{F}}: \bigcirc, s=2 ; \Delta, s=$ $3 ; \square, s=6$. 
ずほぼ同じ值であるが，s>6に長くなると低下する。 連結鎖が長くなると，連結部分が柔軟となってミセルを 形成しやすくなると考えられる。この $\mathrm{cmc}$ と連結鎖長 の関係は，同種の疎水鎖を有する $\mathrm{C}_{n}-\mathrm{s}-\mathrm{C}_{n}$ 㧍よび $\mathrm{C}_{m}{ }^{\mathrm{F}} \mathrm{C}_{3}$ $s-\mathrm{C}_{3} \mathrm{C}_{m}{ }^{\mathrm{F}}$ と同様の傾向である。 $\mathrm{cmc}$ は疎水鎖の種類によっ ても異なり, $\mathrm{C}_{n}-\mathrm{s}-\mathrm{C}_{3} \mathrm{C}_{m}{ }^{\mathrm{F}}>\mathrm{C}_{n}-\mathrm{s}-\mathrm{C}_{n}>\mathrm{C}_{m}{ }^{\mathrm{F}} \mathrm{C}_{3}-\mathrm{s}-\mathrm{C}_{3} \mathrm{C}_{m}{ }^{\mathrm{F}}$ の順に 小さくなり，異種の疎水鎖を有するハイブリッドジェミ 二型界面活性剂が同種疎水鎖のジェミ二型界面活性剂と 比べて高い $\mathrm{cmc}$ を示す。 $\mathrm{C}_{n}-\mathrm{s}-\mathrm{C}_{3} \mathrm{C}_{m}{ }^{\mathrm{F}}$ の $\mathrm{cmc}$ における表 面張力 $\left(\gamma_{\mathrm{cmc}}\right)$ および分子占有面積 $(A)$ 值は, 炭化水 素鎖長，フッ化炭素鎖長捛よび連結鎖長に大きく依存す る。すなわち, 連結鎖長 $s=2$ のとき $\gamma_{\mathrm{cmc}}=15 \sim 22$ $\mathrm{mN} \mathrm{m}^{-1}, A=0.92 \sim 1.3 \mathrm{~nm}^{2}, s=3$ のとき $\gamma_{\mathrm{cmc}}=22 \sim 27$ $\mathrm{mN} \mathrm{m}{ }^{-1}, A=0.92 \sim 1.9 \mathrm{~nm}^{2}, \quad s=6$ のとき $\gamma_{\mathrm{cmc}}=27 \sim 31$ $\mathrm{mN} \mathrm{m}^{-1}, A=1.0 \sim 2.0 \mathrm{~nm}^{2}$ であり, 連結鎖長が最も短 いときに両值が小さく, 気/液界面に効率よく吸着して いることがわかる。逆に連結鎖長が長くなると，その鎖 が湾曲状となり広がって界面に吸着・配向するために, 界面活性が低下寸るものと考元られる。最も高い表面張 力低下能は $\mathrm{C}_{12}-2-\mathrm{C}_{3} \mathrm{C}_{8}^{\mathrm{F}}$ のときに認められ $(15.3 \mathrm{mN} \mathrm{m}$ $\left.{ }^{1}\right)$, 一般のフッ化炭素系界面活性剂がもつ最低の表面張 力 $\left(14 \mathrm{mN} \mathrm{m}^{-1}\right)$ に近い值を示す。また, フッ化炭素鎖 長 $m=8$ の $\mathrm{C}_{n}-s-\mathrm{C}_{3} \mathrm{C}_{8}^{\mathrm{F}}$ の $\gamma_{\mathrm{cmc}}$ 值は, 各連結鎖長において 炭化水素鎖長の増加とともに小さくなるのに対し, $m=$ 6 では $s=2$ 招よび 6 のとき, 炭化水素鎖長が 10 から 12 に増加すると $\gamma_{\mathrm{cmc}}$ 值は逆に大きくなる。これより， $\mathrm{C}_{n}-\mathrm{s}-$ $\mathrm{C}_{3} \mathrm{C}_{m}{ }^{\mathrm{F}}$ は炭化水素鎖とフッ化炭素鎖の長さがほほ等しい ときに，界面で優れた吸着・配向性を示すことが考えら れる。

$\mathrm{C}_{n}-\mathrm{s}-\mathrm{C}_{3} \mathrm{C}_{m}{ }^{\mathrm{F}}$ 水溶液の低濃度 ( $\mathrm{cmc}$ の 10 30 倍の濃度) では，いずれの鎖長に扔いても数 $\mathrm{nm}$ の大きさのミセル を形成していることが DLS および低温透過型電子顕微 鏡 (cryo-TEM) 観察により確認される。 $\mathrm{C}_{8}-3-\mathrm{C}_{3} \mathrm{C}_{6}{ }^{\mathrm{F}}(\mathrm{cmc}$ ×10）が形成するミセルの cryo-TEM 写真を Fig. 6 (a) に示す。ミセルの大きさは, DLSで得られた見かけの 流体力学的直径（2.6 4.0 nm） とほぼ一致する。一方, 高濃度になると溶液に粘性が現れ， $\mathrm{C}_{n}-\mathrm{s}-\mathrm{C}_{3} \mathrm{C}_{m}{ }^{\mathrm{F}}$ の会合体 は連結鎖長 $s$ 拉よび濃度に大きく依存する。 $s=2$ では水 への溶解が低く, $\mathrm{cmc}$ の 10 25 倍以上の濃度で溶液が 白濁する。 $s=3$ では水溶性が向上し, $\mathrm{C}_{12}-3-\mathrm{C}_{3} \mathrm{C}_{m}{ }^{\mathrm{F}}$ は $\mathrm{cmc}$ の 20 40 倍の濃度から高い粘性溶液となる。 $\mathrm{C}_{12}-3$ $\mathrm{C}_{3} \mathrm{C}_{m}{ }^{\mathrm{F}}(m=6,8, \mathrm{cmc} \times 100)$ の貯蔵弾性率 $\left(G^{\prime}\right)$ 打 よび損失弾性率 $(G$ ”) と角周波数 $(\omega)$ の関係を Fig. 7 に示す。 $\mathrm{C}_{12}-3-\mathrm{C}_{3} \mathrm{C}_{6}{ }^{\mathrm{F}}$ は $\omega$ が小さいとき $G^{\prime}<G^{\prime \prime}, \omega$ が大 きくなると逆に $G$ '>G” となる。これは粘弾性体に特 徵的な挙動の Maxwell 型モデルを表し, 紐状ミセルの
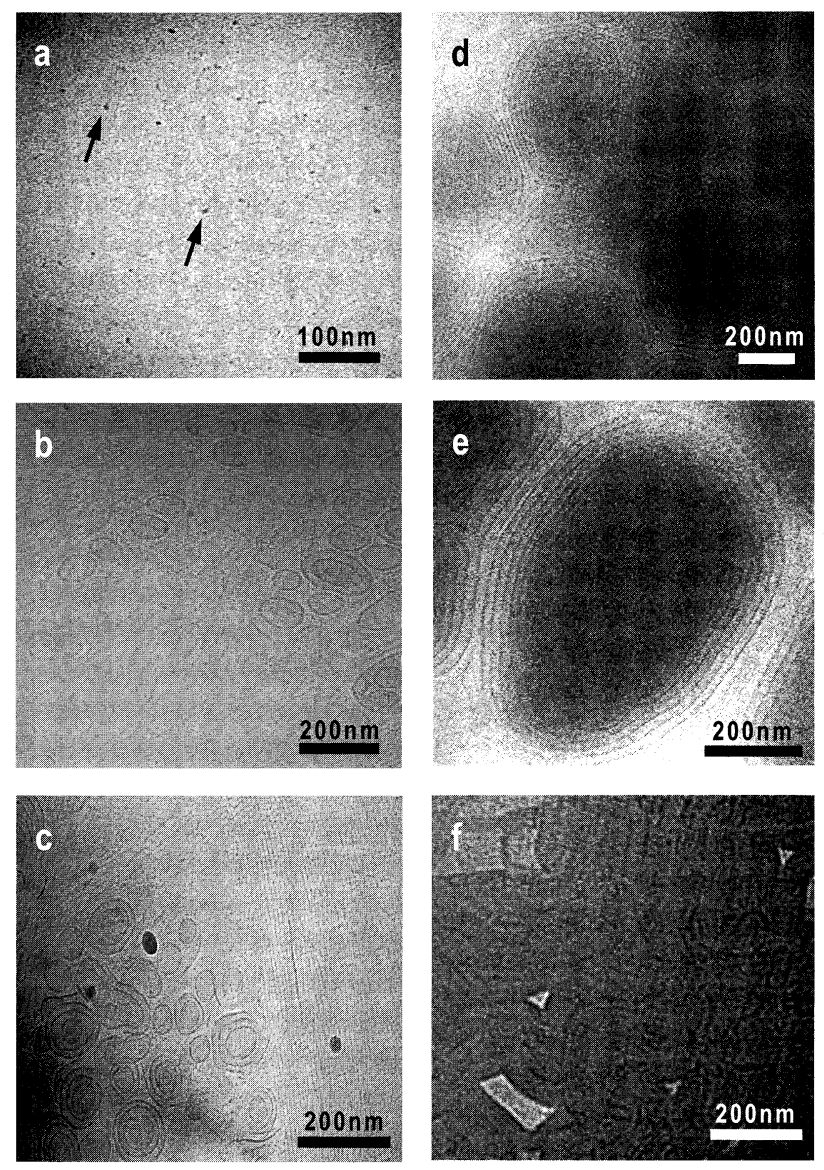

Fig. 6 Cryo-TEM images of $\mathrm{C}_{n}-s-C_{3} \mathrm{C}_{m}{ }^{\mathrm{F}}$ aggregates. (a) $\mathrm{C}_{8}$ $3-\mathrm{C}_{3} \mathrm{C}_{6}^{\mathrm{F}}$ at $73.6 \mathrm{mmol} \mathrm{dm} \mathrm{mos}^{-3}(\mathrm{cmc} \times 10)$, (b, c) $\mathrm{C}_{12}-3-$ $\mathrm{C}_{3} \mathrm{C}_{8}{ }^{\mathrm{F}}$ at $34.7 \mathrm{mmol} \mathrm{dm}^{-3}(\mathrm{cmc} \times 100)$, (d, e) $\mathrm{C}_{12}-3-$ $\mathrm{C}_{3} \mathrm{C}_{8}^{\mathrm{F}}$ at $139 \mathrm{mmol} \mathrm{dm}^{-3}(\mathrm{cmc} \times 400)$, (f) $\mathrm{C}_{12}-6$ $\mathrm{C}_{3} \mathrm{C}_{6}^{\mathrm{F}}$ at $142 \mathrm{mmol} \mathrm{dm}^{-3}(\mathrm{cmc} \times 100)$.

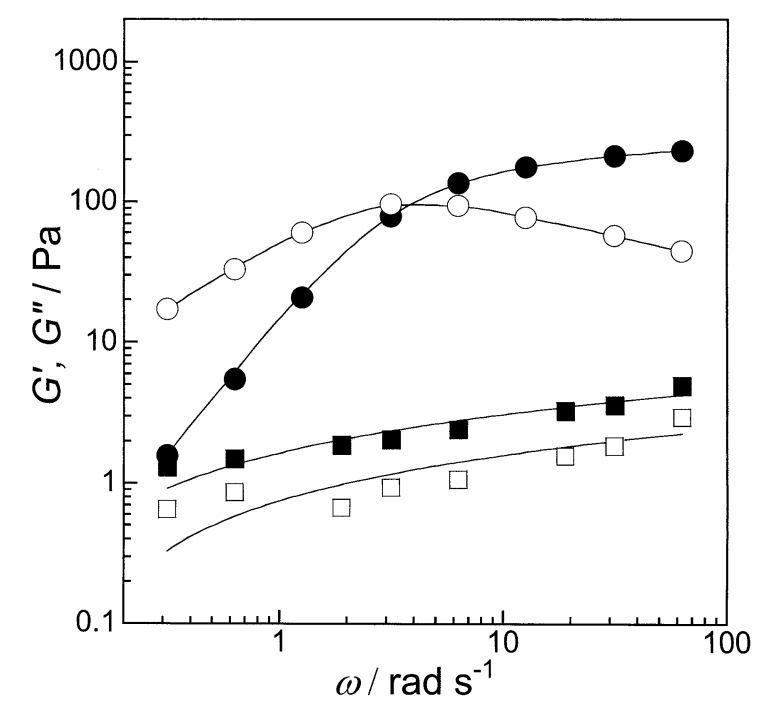

Fig. 7 Frequency dependence of storage and loss moduli for $\mathrm{C}_{12}-3-\mathrm{C}_{3} \mathrm{C}_{m}{ }^{\mathrm{F}}$ solution at $\mathrm{cmc} \times 100 . \mathrm{C}_{12}-3-\mathrm{C}_{3} \mathrm{C}_{6}{ }^{\mathrm{F}}$ : $G^{\prime} ; \bigcirc, G^{\prime \prime}, \mathrm{C}_{12}-3-\mathrm{C}_{3} \mathrm{C}_{8}{ }^{\mathrm{F}}: \mathbf{\square}, G^{\prime} ; \square, G^{\prime \prime}$. 
形成を示唆する。一方, フッ化炭素鎖が長い $\mathrm{C}_{12}-3-\mathrm{C}_{3} \mathrm{C}_{8}{ }^{\mathrm{F}}$ では常に $G^{\prime}>G^{\prime}$ である。これは一般にゲル溶液で見 られる挙動と一致する。このとき cryo-TEM 観察より, 紐状ミセルとベシクルの 2 つ会合体の共存が確認され (Fig.6（b）），なかには多重層ベシクルも見られる（c）。 濃度をさらに増加させる $(\mathrm{cmc} \times 400)$ と，600～800 nm

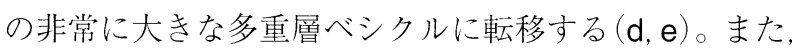
連結鎖が長い $s=6$ では， $s=3$ とは異なる粘性溶液とな り, $\mathrm{C}_{12}-6-\mathrm{C}_{3} \mathrm{C}_{6}{ }^{\mathrm{F}}(\mathrm{cmc} \times 100)$ では紐状ミセルの形成が確 認される（f）。このように，ハイブリッドジェミニ型界 面活性剤のフッ化炭素抢よび炭化水素の両鎖長と連結鎖 長を変えることで，形成する会合体の構造は劇的に異な り, 大変興味深い。詳細は, 今後の著者らの論文を参照 していただきたい。

\section{5 おわりに}

カルボン酸塩を有するフッ素系ジェミニ型アニオン界 面活性剤，四級アンモニウム塩を有するフッ素系ジェミ 二型カチオン界面活性剤，フッ化炭素と炭化水素の異種 の疎水鎖を有するハイブリッドジェミニ型カチオン界面 活性剂の界面化学的性質㧍よび水溶液中で形成する会合 体の特性について概説した。これらは対応するフッ素系 1 鎖型界面活性剤と比べて低い $\mathrm{cmc}$ を有し, $20 \mathrm{mN} \mathrm{m}^{-1}$ 以下の優れた表面張力低下能を示し，また，フッ化炭素 鎖長および濃度を変えることで, 水溶液中で形成する会 合体の構造が劇的に変化することは大変興味深い結果で ある。

フッ素系ジェミニ型界面活性剂に関する研究は，高価 なフッ素原料や合成の複雑さを理由に敬遠されがちで, 現在のところ他のジェミ二型界面活性剤と比べて遅れて いる。応用研究が大いに期待できるフッ素系ジェミニ型 界面活性剤は, 炭化水素系ジェミ二型界面活性剤と同様, 多種多様な分子設計が可能であるので，今後，合成，基 礎物性, 応用面での研究が進み, フッ素系ジェミ二型界 面活性剂ならではの特性が数多く明らかになることを期 待したい。筆者らも, さらなる性能および機能性が付与 したフッ素系ジェミ二型界面活性剤を開発したいと考え ている。

最後に, 本研究の一部は昭和薬科大学松岡圭介講師と の共同研究であることを付記する。

\section{文 献}

1) R. Zana \& J. Xia, Gemini Surfactants; Synthesis, Interfacial and Solution-Phase Behavior, and Applications, Marcel Dekker, New York (2003)

2) M. Okahara, A. Masuyama, Y. Sumida \& Y.-P. Zhu, J. Jpn. Oil Chem. Soc., 37, 746 (1988).
3) F. M. Menger \& C. A. Littau, J. Am. Chem. Soc., 113, 1451 (1991).

4) R. Zana \& Y. Talmon, Nature, 362, 228 (1991).

5) M. J. Rosen, CHEMTECH, 30 (1993).

6) F. Marty, E. Bollens, E. Rouvier \& A. Cambon, J. Fluorine Chem., 48, 239 (1990).

7) M. Gaysinski, L. Joncheray, F. Guittard, A. Cambon \& P. Chang, J. Fluorine Chem., 74, 131 (1995).

8) R. Oda, I. Huc, D. Danino \& Y. Talmon, Langmuir, 16, 9759 (2000).

9) F. Guittard, \& S. Geribaldi, J. Fluorine Chem., 107, 363 (2001).

10) R. Oda, R. Laguerre, I. Huc \& B. Desbat, Langmuir, 18, 9659 (2002)

11) L. Massi, F. Guittard \& S. Géribaldi, Prog. Colloid Polym. Sci., 126, 190 (2004).

12) J. Nishida, A. Brizard, B. Desbat \& R. Oda, J. Colloid Interface Sci., 284, 298 (2005).

13) Y. Li, P. Li, J. Wang, Y. Wang, H. Yan, C. Dong \& R. K. Thomas, K. J. Colloid Interface Sci., 287, 333 (2005).

14) T. Yoshimura, A. Ohno \& K. Esumi, Langmuir, 22, 4643 (2006).

15) T. Asakawa, T. Okada, T. Hayasaka, K. Kuwamoto, A. Ohta \& S. Miyagishi, Langmuir, 22, 6053 (2006).

16) S. Dong, X. Li, G. Xu \& H. Hoffmann, J. Phys. Chem. B, 111, 5903 (2007).

17) K. Matsuoka, T. Yoshimura, T. Shikimoto, J. Hamada, M. Yamawaki, C. Honda \& K. Endo, Langmuir, 23, 10990 (2007).

18) K. Matsuoka, T. Yoshimura, M. Bon, C. Honda \& K. Endo, Langmuir, 24, 5676 (2008).

19) A. Ohno, A. Kushiyama, Y. Kondo, T. Teranaka \& N. Yoshino, J. Fluorine Chem., 129, 577 (2008).

20) T. Yoshimura, M. Bon, K. Matsuoka, C. Honda \& K. Endo, J. Colloid Interface Sci., 339, 230 (2009).

21) T. Kawase, J. Iidzuka \& T. Oida, J. Oleo Sci., 59, 483 (2010).

22) P. X. Li, C. C. Dong, R. K. Thomas \& Y. L. Wang, Langmuir, 27, 656 (2011).

23) Y. Li, P. Li, C. Dong, X. Wang, Y. Wang, H. Yan \& R. K. Thomas, Langmuir, 22, 42 (2006).

24) P. X. Li, C. C. Dong \& R. K. Thomas, Langmuir, 27, 1844 (2011)

25) E. Kissa, Fluorinated Surfactants and Repellents, $2^{\text {nd }}$ ed., Marcel Dekker, New York (2001).

26) F. M. Menger \& C. A. Littau, J. Am. Chem. Soc., 115, 10083 (1993).

27) L. D. Song \& M. J. Rosen, Langmuir, 12, 1149 (1996).

28) R. Zana, J. Colloid Interface Sci., 246, 182 (2002).

29) K. Shinoda \& T. Hirai, J. Phys. Chem., 81, 1842 (1977).

30) K. Shinoda, M. Hato \& T. Hayashi, J. Phys. Chem., 76, 909 (1972).

31) Th. Dam, J. B. F. N. Engberts, J. Karthäuser, S. Karaborni \& N. M. van Os, Colloids Surf., A, 118, 41 (1996).

32) H. Kunieda \& K. Shinoda, J. Phys. Chem., 80, 2468 
(1976).

33) E. Schuierer, Tenside, 13, 1 (1976).

34）羽藤正勝，篠田耕三，日化，91，27（1970）.

35) H. B. Klevens, J. Phys. Colloid Chem., 52, 130 (1948).

36) R. Zana \& H. Lévy, Colloids Surf., A, 127, 229 (1997).

37) J. C. Ravey, A. Gherbi \& M. J. Stebe, Prog. Colloid Polym. Sci., 259, 761 (1981).

38) C. Selve, J. C. Ravey, C. El Moudjahid, E. M. Moumni \& J. J. Delpuech, Tetrahedron, 47, 411 (1991).
39) W. Guo, Z. Li, B. M. Fung, E. A. O’Rear \& J. H. Harwell, J. Phys. Chem., 96, 6738 (1992).

40) N. Yoshino, J. Jpn. Soc. Colour Mater. (SHIKIZAI), 74, 196 (2001).

41）好野則夫，オレオサイエンス，1，649（2001）.

42) Y. Kondo \& N. Yoshino, Current Opinion in Colloid Interface Sci., 10, 88 (2005).

43）奥田葵, 吉村倫一, 日本油化学会第 48 回年会 - 講演要 旨集, 名古屋, p.121 (2009). 